\title{
A case of haemochromatosis and diabetes: a missed opportunity
}

\author{
HIANG LENG TAN${ }^{1}$, FEAZ BABWAH², MUHAMMAD IMRAN BUTT³, NAJEEB WAHEED²
}

\section{Background}

Haemochromatosis is the most common inherited disorder that causes the body to retain excessive amounts of iron. ${ }^{1}$ It is ten times more common in males and results in iron accumulation in various organs, in particular the liver and pancreas. The prevalence in various northern European populations is estimated to be as high as 1 in 200.

The relationship between haemochromatosis and diabetes mellitus has been well established and documented in medical literature, hence the term 'bronze diabetes'. Diabetes affects $30 \%$ to $60 \%$ of patients with hereditary haemochromatosis. ${ }^{2}$ Although the underlying pathophysiology of diabetes in patients with haemochromatosis has not been fully elucidated, it is thought to be multifactorial.

\section{Case history}

A 60 year old male patient with a background of epilepsy presented to his primary care physician in 2003 with an episode of candida balanitis. He had a two month history of osmotic symptoms and two stone weight loss. His random blood glucose was $21.2 \mathrm{mmol} / \mathrm{L}$. Although he was not ketoacidotic and his weight was $70 \mathrm{~kg}$, given the brief history, he was diagnosed with type 1 diabetes. He started twice daily mix insulin regime and remained relatively well controlled with $\mathrm{HbA}_{1 c}$ ranging between $6.5 \%$ and $7.7 \%$ and free of diabetes related complications. He had no family history of diabetes and his drug history included phenytoin $200 \mathrm{mg}$ bd.

At the time of presentation he was noted to have elevated transaminases: AST $49 \mathrm{IU} / \mathrm{L}$ (reference range 0-38 IU/L) and ALT $69 \mathrm{IU} / \mathrm{L}$ (reference range $0-38 \mathrm{IU} / \mathrm{L}$ ). He drank about 8 units of alcohol per week and had no risk factors for hepatitis. Abdominal ultrasound showed a slightly enlarged and echogenic liver which was thought to be secondary to fatty infiltration. Monitoring of liver function continued for 6 years and

Weston General Hospital, Weston-super-Mare, UK

2 The County Hospital, Hereford, Wye Valley NHS Trust, UK

3 Peterborough City Hospital, Edith Cavell Campus, Bretton Gate,

Peterborough, Cambridgeshire, UK

Address for correspondence: Dr Hiang Leng Tan Department of Diabetes and Endocrinology, Weston General Hospital, Weston-super-Mare, BS23 4TQ, UK

Telephone: 01934636363

E-mail: hiangleng@doctors.org.uk

Br J Diabetes Vasc Dis 2014;14:161-163

http://dx.doi.org/10.15277/bjdvd.2014.038

\author{
Abbreviations and acronyms \\ ALT \\ AST aspartate transaminase \\ $\mathrm{HbA1c}$ glycated haemoglobin \\ GADA glutamic acid decarboxylase antibodies
}

Table 1 Liver screen

\begin{tabular}{|c|c|c|}
\hline Test & Result & $\begin{array}{l}\text { Reference } \\
\text { range }\end{array}$ \\
\hline Anti-nuclear antibodies & negative & \\
\hline Anti-mitochondrial antibody & negative & \\
\hline Anti-smooth muscle antibody & negative & \\
\hline Anti-liver kidney microsomal antibody & negative & \\
\hline Anti-endomysial antibody & negative & \\
\hline Alfa-fetoprotein & 2 & $0-10 \mathrm{KU} / \mathrm{L}$ \\
\hline Hepatitis B surface antigen & negative & \\
\hline Hepatitis C antibody & not detected & \\
\hline Iron & 29 & $13-45 \mu \mathrm{mol} / \mathrm{L}$ \\
\hline Iron binding capacity & 26 & $49-70 \mu \mathrm{mol} / \mathrm{L}$ \\
\hline Ferritin & 4798 & $15-250 \mu \mathrm{g} / \mathrm{L}$ \\
\hline Transferrin saturation & $100 \%$ & \\
\hline
\end{tabular}

unfortunately no definitive diagnosis was made.

In 2009, a comprehensive liver screen was requested as shown in table 1. This confirmed a hugely elevated ferritin level, thus raising the possibility of haemochromatosis.

Subsequent genetic testing for the C282Y gene confirmed type 1 hereditary haemochromatosis. He was referred to the gastroenterology team and commenced treatment with weekly venesections. Repeated ultrasound scans were negative for hepatic cirrhosis.

In February 2013 the patient had a hospital admission for labyrinthitis and was found to have had recurrent hypoglycaemic episodes. He seemed to have lost his hypo-awareness and was observed to have very tight control with an $\mathrm{HbA}_{1 \mathrm{c}}$ of $5.6 \%$ $(38 \mathrm{mmol} / \mathrm{mol})$. He was referred to the endocrinology team and as a new patient we reviewed his notes and found that his deranged liver function tests actually dated back to 1996, which in fact pre-dated his diabetes. It was only then thought that his diabetes may have been secondary to his undiagnosed haemochromatosis rather than type 1 diabetes (See Table 2 for trend of liver function tests, ferritin and $\mathrm{HbA}_{1 c}$ from 2003 onwards). 
Table 2 Trend of liver function tests

\begin{tabular}{|c|c|c|c|c|c|c|c|c|}
\hline & 2003 & 2004 & 2008 & 2009 & 2010 & 2011 & 2012 & 2013 \\
\hline AST (IU/L) & 49 & 47 & 52 & 51 & 58 & 29 & 32 & 25 \\
\hline ALT (IU/L) & 69 & 77 & 50 & 56 & 60 & 26 & 26 & 25 \\
\hline ALP (IU/L) & 173 & 188 & 177 & 181 & 163 & 154 & 153 & 118 \\
\hline Bilirubin $(\mu \mathrm{mol} / \mathrm{L})$ & 6 & 6 & 5 & 4 & 2 & 2 & 5 & 5 \\
\hline $\mathrm{HbA}_{1 \mathrm{c}}(\%)$ & 10.6 & 9.4 & 7.3 & 7.7 & 5.9 & 5.6 & 6.5 & 6.0 \\
\hline $\mathrm{HbA}_{1 \mathrm{c}}(\mathrm{mmol} / \mathrm{mol})$ & 92 & 79 & 56 & 61 & 41 & 38 & 48 & 42 \\
\hline Haemoglobin (g/dL) & 14.2 & 14.3 & 12.6 & 13.5 & 11.4 & 12.8 & 12.8 & 12.7 \\
\hline
\end{tabular}

Table 3 Pituitary function test and short synacthen test results

\begin{tabular}{lll}
\hline Test & Results & Normal range \\
TSH & 1.33 & $0.25-0.5 \mathrm{mU} / \mathrm{L}$ \\
FT4 & 11.2 & $12-25 \mathrm{pmol} / \mathrm{L}$ \\
FSH & 1.7 & $2-17 \mathrm{U} / \mathrm{L}$ \\
$\mathrm{LH}$ & 2.6 & $1-7 \mathrm{U} / \mathrm{L}$ \\
Prolactin & 376 & $86-324 \mathrm{mU} / \mathrm{L}$ \\
IGF-1 & 2.1 & $8.9-32 \mathrm{nmol} / \mathrm{L}$ \\
Testosterone & 1.6 & $7-26 \mathrm{nmol} / \mathrm{L}$ \\
Baseline cortisol & 378 & $\mathrm{nmol} / \mathrm{L}$ \\
$1 / 2$ hour cortisol & 1036 & $\mathrm{nmol} / \mathrm{L}$ \\
1 hour cortisol & 1307 & $\mathrm{nmol} / \mathrm{L}$
\end{tabular}

He was still on insulin therapy and had no documented ketoacidotic episodes. There were no reports of him having missed insulin doses with any undue effects. To further clarify his diabetes diagnosis, GADA were requested. This was negative at $<5 \mathrm{IU} / \mathrm{mL}$ (reference range $0-10 \mathrm{IU} / \mathrm{mL}$ ). Anti-islet cell antibodies were not done.

Baseline pituitary function tests and a short synacthen test were requested in view of his recurrent hypoglycaemic episodes (see Table 3). On further questioning he was also experiencing low energy, loss of libido and erectile dysfunction. The patient was found to have hypogonadotrophic-hypogonadism secondary to his haemochromatosis. He was started on six-weekly testosterone injections with good effect. He also had an MRI scan of his pituitary which was normal.

\section{Discussion}

The association between haemochromatosis and diabetes was first recognised in the late 1800s, when doctors coined the term 'bronze diabetes'. ${ }^{3}$ The aetiology is multifactorial. Selective betacell damage, due to uptake of iron, leads to impaired insulin synthesis and release. ${ }^{4}$ In addition: liver fibrosis leads to high levels of circulating insulin and thus insulin resistance. ${ }^{1}$ There also seems to be a genetic link. A few studies have shown the incidence of the C282Y mutation of the HFE gene to be higher in people with type 2 diabetes than it is in the general population. ${ }^{1,4}$

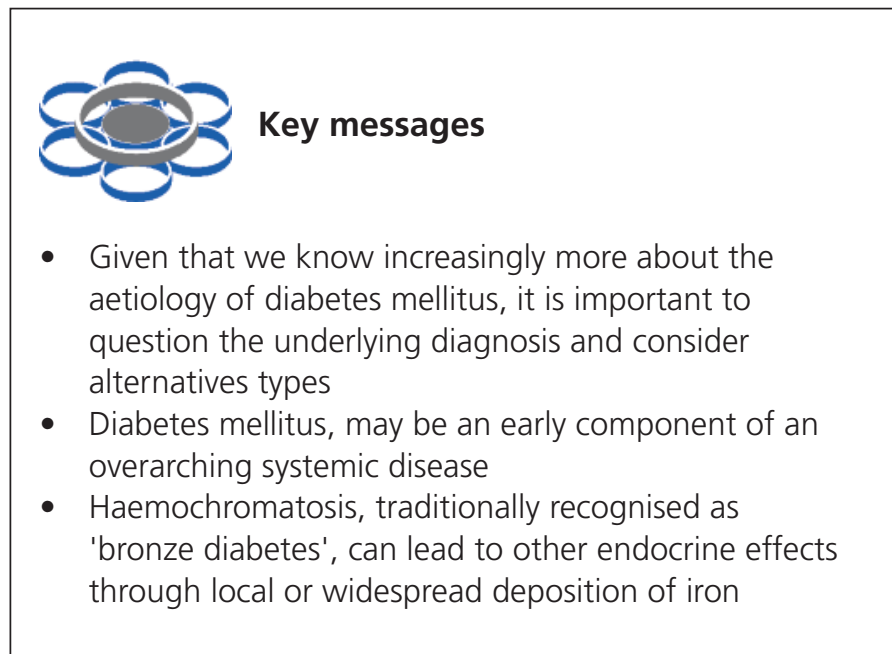

Research done by the Royal College of General Practitioners and NHS Diabetes reports that some 50,000 patients in England have been classified with the wrong type of diabetes. ${ }^{5}$ In our patient, liver enzymes were elevated at the time of diabetes diagnosis, but it was not until 6 years later that he was diagnosed with haemochromatosis and it took a further 3 years to determine that his diabetes was secondary to this rather than type 1 . If he had been screened and treated for haemochromatosis in 1996 when deranged liver function tests were first identified, this would have had a significant impact on his disease related complications and life expectancy. There is overwhelming evidence that institution of phlebotomy therapy before cirrhosis and/or diabetes develop will significantly reduce morbidity and mortality. ${ }^{6}$

While this patient was found to be too tightly controlled at the time his diabetes classification was in question, these $\mathrm{HbA}_{1 \mathrm{c}}$ values may have been misleading as he was now mildly anaemic (haemoglobin $12.7 \mathrm{~g} / \mathrm{dL}$ ) and still having regular venesections. Ideally fructosamine levels should have been used for correlation. Fructosamine gives the average glucose levels over the past 2-3 weeks, which coincide with the half-life of albumin and is very useful in circumstances where there is a shortened red blood cell life span. ${ }^{7}$

The absence of GADA in this patient some 10 years after 
diagnosis is still reliable in excluding type 1 diabetes. GADA are present in $75-90 \%$ of type 1 diabetic patients at diagnosis. ${ }^{8}$ In addition, unlike islet cell antibodies, GADA persist for many years after diagnosis in a sizable proportion of patients with type 1 diabetes, and can therefore help in characterising diabetes in long-standing patients. ${ }^{8}$

After diabetes, hypogonadotrophic hypogonadism is the most common endocrinopathy with hereditary haemochromatosis. ${ }^{9}$ Several studies report a prevalence rates of $10-100 \%$. One has to take into account the natural decline in testosterone levels in males that occurs with aging. It is estimated to be $1.6 \%$ per year according to the Massachusetts Male Aging Study. ${ }^{10}$ Both testosterone replacement and aggressive venesection can vastly improve the quality of life of these patients as well as impact on bone mass. ${ }^{9}$

\section{Conflict of interest None. Funding sources None.}

\section{References}

1. Wieringa D, Rankin M. Hemochromatosis and diabetes mellitus: the 'bronze diabetes'. Australian Diabetes Educator 2010:13:4
2. Hatunic M, Finucane FM, Brennan AM, Norris S, Pacini G, Nolan JJ. Effect of iron overload on glucose metabolism in patients with hereditary hemochromatosis. Metabolism 2010;59:380-4. http://dx.doi.org/10.1016/j.metabol.2009.08.006

3. Dinsmoor RS. Hemochromatosis. 2006 May (cited 2013 June 25). Available from http://www. diabetesselfmanagement.com/Articles/DiabetesDefinitions/hemochromatosis/

4. Capell P. Haemochromatosis in type 2 diabetes. Clinical Diabetes 2004; 22:101-02. http://dx.doi.org/10.2337/diaclin.22.2.101

5. Alert over misdiagnosis of diabetes. 2011 Mar (cited 2013 June 25). Available from http://www.diabetes.co.uk/news/2011/Mar/alert-overmisdiagnosis-of-diabetes-94523038.html

6. Niederau C, Fischer R, Purschel A, et al. Long-term survival in patients with hereditary hemochromatosis. Gastroenterology 1996;110:110719. http://dx.doi.org/10.1053/gast.1996.v110.pm8613000

7. Fructosamine. 2013 Mar (cited 2013 June 20). Available from http://labtestsonline.org/understanding/analytes/fructosamine/tab/test

8. GAD antibodies. 2013 Oct (cited 2013 June 27). Available from http://www.diapedia.org/type-1-diabetes-mellitus/gad-antibodies

9. McDermott JH, Walsh $\mathrm{CH}$. Hypogonadism in hereditary haemochromatosis. JCEM 2005:90:2451-5.

10. Feldman HA, Longcope C, Derby $C$, et al. Age trends in the level of serum testosterone and other hormones in middle-aged men: longitudinal results from the Massachusetts Male Aging Study. JCEM 2002; 87:589-98.

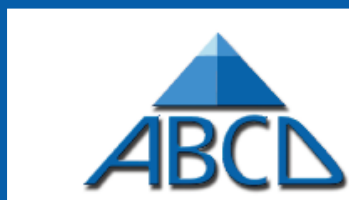

Association of British Cliniteal Diabetologist

\section{Exenatide weekly (QW) (Bydureon) Nationwide Audit Launched}

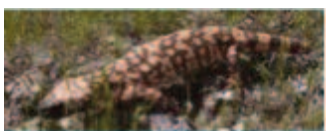

\section{Does your centre use exenatide QW?}

If yes, REGISTER YOUR CENTRE! http://diabetologists-abcd.org.uk/n3/ExenatideQW_Audit.htm

$A B C D$ has launched a nationwide audit of exenatide QW (Bydureon) in the UK to assess real clinical efficacy and safety \& inform future practice and guidelines

- you are invited to submit your patients' anonymised routinely collected data

- using an easy-to-use online tool hosted on the secure NHS network (N3)

- we can provide easy-to-complete paper proformas for use if preferred

- if contributing, you will be able to analyse your local data easily

Please remember: - the more data, the more significant the result will be - all contributors will be listed in publications arising from data submission 